\title{
Implementation of Lean Manufacturing in a Cement Industry
}

\author{
Majed Masmali \\ Industrial Engineering Department \\ College of Engineering \\ Northern Border University \\ Arar, Saudi Arabia \\ majed.masmali@nbu.edu.sa
}

\begin{abstract}
The lean manufacturing concept is a systematic minimization of waste and non-value activities in production processes introduced by the Toyota production system. In this research, lean manufacturing is implemented in a cement production line. Value Stream Mapping (VSM) is applied to give a clear picture of the value chain in cement production processes and to highlight the non-value-added in the shop floor. To begin, the existing VSM is constructed based on the information and data gathered during visiting and observing the manufacturing process in the firm. As a result, the excess inventory between workstations was identified as a major waste generation, hence, the proposed VSM conducts further improvement and makes action plans to alleviate the unwanted activities. Then, the takt time to ensure smooth material flow and to avoid any occurring delay or bottleneck in the production line was figured out. The supermarket pull-based production control is suggested to be adopted in the future map. Two pull production strategies are selected in this case. The first is applying the Kanban system to control the level of inventory between workstations. The other is the CONWIP approach to control the amount of work in process to the entire production line. The outcome of the proposed models indicates a decrease of the none-value time from 23 days in the current state to about 4 and 2 days in Kanban and CONWIP systems respectively, so the CONWIP was suggested as most efficient. Some suggestions for further research are also mentioned.
\end{abstract}

Keywords-cement industry; CONWIP; Kanban; pull systems; value stream mapping; lean manufacturing

\section{INTRODUCTION}

The cement industry is the most prominent building material industry, contributing greatly to the global and national economy and growth. Since cement is a primary construction material, cement economics are closely related to the construction sector. The history of the cement industry goes back to 1824, when the Portland cement was invented [1-3]. Thereafter, the cement industry has developed and the volume of production has increased steadily. The raw materials include clay limestone transform into clinker. The clinker is transformed into cement by adding gypsum and other materials. The cement production process passes through numerous workstations including crushers, milling, rotary kiln, and milling finishing cements. Between these manufacturing processes there are stocks and silos between workstations. The cement is made by mixing lime, clay, and iron materials in certain proportions to give the coated materials calcium, silica, corundum, and iron oxide. These raw materials are then grinded well to facilitate the burning process, which takes place at a temperature of $1500^{\circ} \mathrm{C}$. This material after burning is called clinker. The lime materials for clinker make up about $90 \%$ of the cement mass, as gypsum material is added to it in proportions ranging from 3 to $5 \%$ to control the hardening and cohesion of the cement, which varies in terms of the added amount according to the type produced [1-6].

This series of activities from the suppliers to the customers is known as the value chain. The customer order is considered as the input of flow information, while the output is the order fulfillment. The aim of the value chain is to make the enterprise competitive [7, 8]. In order to ensure the sustainability of production and competitiveness with a view to improve the cement production line, production management principles should be implemented in this industry. The purpose of these strategies is to make decisions to develop and improve the shop floor operations in cement factories. One of these aspects is reducing the work in process, since the excess inventory could contribute to the holding cost. In addition, no value is added to the clinker and cement which are stored in the factory. Therefore, the lean manufacturing concept is chosen in this research to be implemented in the production processes. It is a systematic minimization of non-value activities in the manufacturing systems $[9,10]$.

The lean manufacturing philosophy has been introduced in the Toyota production system. The principle of this technique is to eliminate the waste that occurs in the production process. The waste in lean manufacturing comes from over production, waiting, transportation, over processing, movement, inventory, and defects [9-11]. Liker [12] extended the definition by considering the non-utilized talents as a waste. When the lean manufacturing is implemented a sort of tools must be used to reduce and eliminate the added non-value, tools such as pull system, value stream map, Heijunka, SMED, Total Productive Maintenance (TPM), Poka-yoke 5'S, and Kaizen [9-11].

Lean manufacturing has been implemented to different manufacturing aspects. This part will focus on the studies 
related to the cement industry. Authors in [13] implemented the lean philosophy to improve the cement production line performance. Maximum efficiency and minimum lead time and production cost can be achieved if the right training is provided to the employees and a motivation system is introduced to the workplace environment. Authors in [14] developed an approach for the application of lean manufacturing in the cement industry. A numerical model was built to compare the current and future state VSM. The output of the proposed model outlined that there was an improvement in throughput and reduction in lead time. In addition, the Kanban was applied to study the effects of the inventory in cement manufacturing. Authors in [15] implemented TPM in the cement production line. Authors in [16] applied VSM in order to explore the various non-value added activities in the supply chain of a cement factory. Authors in [17] determined the essential points for implementing the management of Just in Time philosophy on the cement industry in Pakistan. Inventory management, production design, production plan, supply chain integration, and total quality control have been selected as factors in order to eliminate the waste of resources. Authors in [18] demonstrated a numerical approach to study the cement manufacturing lines taking into account the supply chain management and its effect on Just in Time production. Authors in [19] proposed a simulation model to study the supply chain management in cement industry. Authors in [20] introduced a matrix for the waste relationship, a questionnaire of waste assessment, and a value stream analysis approach to eliminate the waste in cement production. In the previous study, the approach consists of four stages which are identification of waste, value stream analysis, fishbone diagram, and failure mode and effect analysis. The literature review shows significant contributions that should be further researched in terms of the application of lean production in the cement industry.
In the current article, the VSM tool is applied in a cement production line. The main contribution of this article is the implementation of lean manufacturing in a cement factory in order to control and minimize the level of work in process. There is an opportunity to compare the outcomes of the proposed pull production systems which are Kanban and CONWIP strategies among the push production system.

\section{RESEARCH METHDOLOGY}

In this study, VSM is applied to implement lean manufacturing towards a cement production line. It is a significant lean tool that identifies the potential waste and forms a clear picture of the production process in order to build a road map of improving the production process. The four main steps of implementing VSM [11] are given in Figure 1.

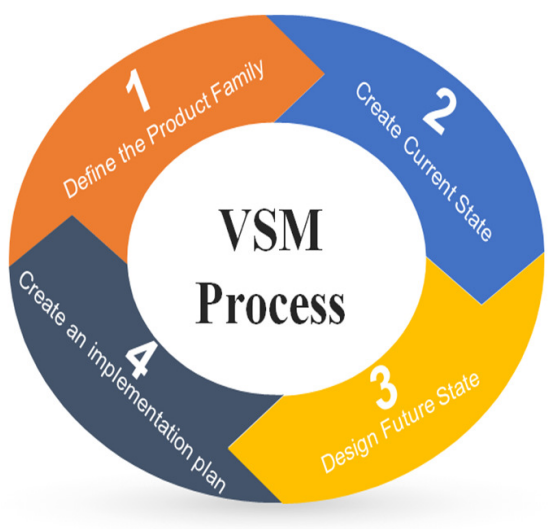

Fig. 1. Value stream mapping process.

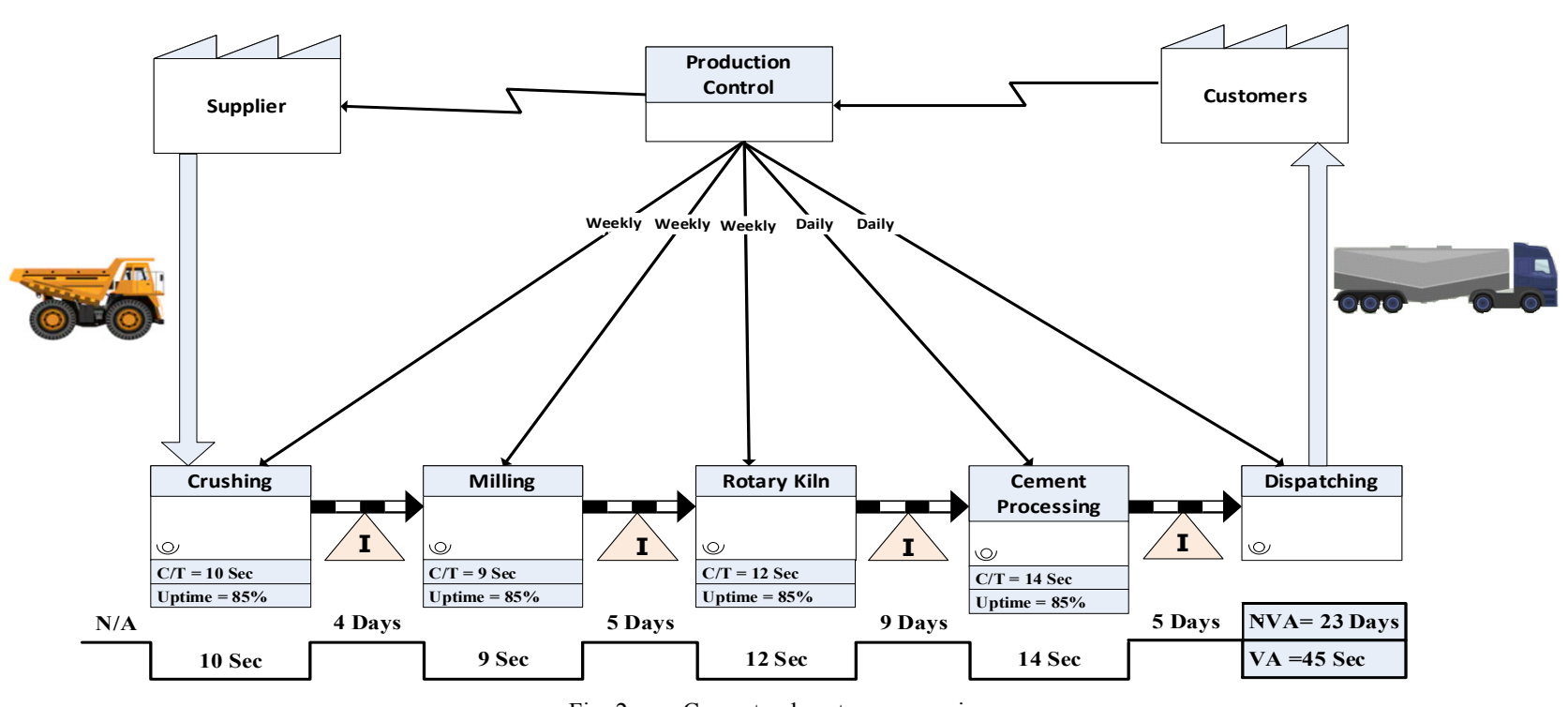

Fig. 2. Current value stream mapping.

The research study is conducted at a cement factory. The design capacity of this plant is 6,000 tons per day, whereas the annual production is 1.98 million tons, based on 330 working days per year and taking into account the shutdown for 
maintenance. The current VSM is constructed according to the guidelines in [11]. The relevant data and information associated with the production processes, i.e. information flow, physical flow, and time line are gathered. Information flow is related to the customer requests (from the sales department or from orders from the factory's website) where the productionplanning can be conducted. The second element is material flow. Data were taken during visiting the factory and observing the progress of operations and workflow in the shop floor, in order to understand the cement manufacturing industry processes. The cycle times are taken as the average cycle time from production department records. When it comes to the inventories, there are four stores between each workstation. The average time of materials stored in silos has been reported. The down time for each process has been assumed to be $15 \%$. The third element is trend line. It consists of two time components. The first timeline is the non-value added time. It is also called the lead time or waiting time. It is the summation of the amount of each inventory. Another timeline is value added time. It can be computed by the summation of cycle times for each workstation process.

The current VSM is illustrated in Figure 2. It can be seen that from the trend line, the non-value time is about 23 days, whereas the value time is approximately 45 seconds.

\section{THE PROPOSED FUTURE VALUE STREAM MAPPING}

Based on the existing VSM outcomes, it is necessary for the proposed VSM model to eliminate the non-value added in the cement production line. First of all, the maximum time required to meet the customer demands should be identified in order to avoid any waste or delay of delivery. The takt time is computed as [11]:

$$
\text { Takt Time }=\frac{\text { Available working time }}{\text { Customer demand }}
$$

The maximum demand required by customers for the cement production line is about 6000 tons per day. As the plant runs 24 hours a day, the available working time is 86,400 seconds. Therefore, the takt time can be obtained as:

$$
\text { Takt Time }=\frac{86400 \text { seconds }}{6000 \text { tons per day }}=14.4 \text { seconds per ton }
$$

This means that 1 ton of cement needs to be produced in 14.4 seconds. Subsequently, the overall takt time is compared against cycle time for each workstation as shown in Figure 3. In addition, the current production strategy for the factory follows the push production control shown in Figure 4.

Each workstation pushes completed work to the next workstation. As a result, the inventory level between workstations is increased. In the proposed future map, pull production is applied to produce the right quantity of products at the right time. A common approach of pull based production process is the Kanban. One of its benefits is the control of the level of inventory between workstations [21]. However, authors in [22-25] introduced another pull system, Constant Work In Process (CONWIP), to control the production line. Both the above pull approaches were implemented in the future state maps.

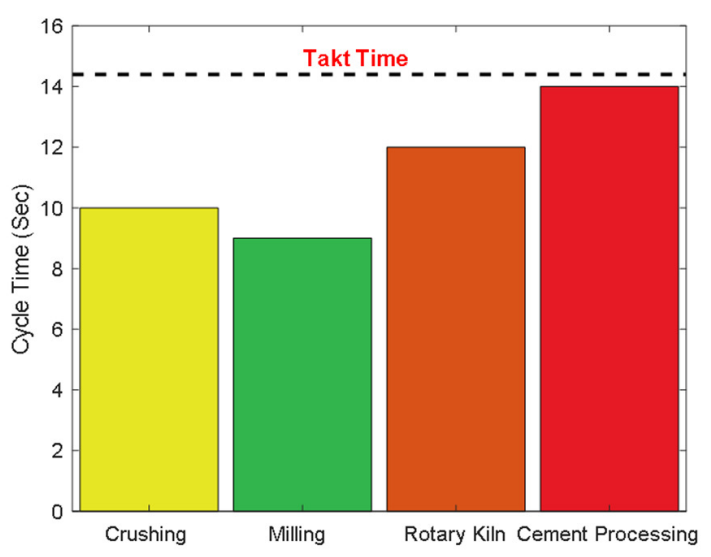

Fig. 3. Cement production line balancing.

\section{A. Kanban}

Kanban is a lean tool associated with the pull production system and Just in Time production [7-9]. To demonstrate the use of the Kanban pull system to control the excess inventory, the following assumptions are made: The cement production line is divided into four stages, as shown in Figure 5. Each phase consists of a process workstation which consists of the input buffer, processes, and the output buffer. The number of Kanbans is computed [26] as (2):

$$
N=\frac{d L+S}{C}
$$

where $d$ is the average demand, $L$ is the lead time, $S$ is the safety stock, and $C$ is the container size.

To illustrate, the Withdrawal Kanban (WK) is transferred from the succeeding workstation to the preceding workstation and placed in the output buffer of the workstation and the production for the rotary kiln workstation respectively. For further details, the WK3 and PK3 are assigned as the numbers of withdrawal and production for the rotary kiln workstation respectively. The clinker container with Withdrawl Kanban (WK3) is moved from the cement processing station into the rotary kiln station and placed in the output of this workstation. The future state maps for the Kanban approach is shown in Figure 6.

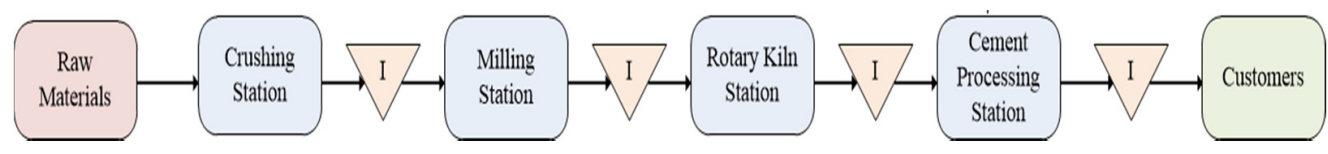

Fig. 4. Push production system. 


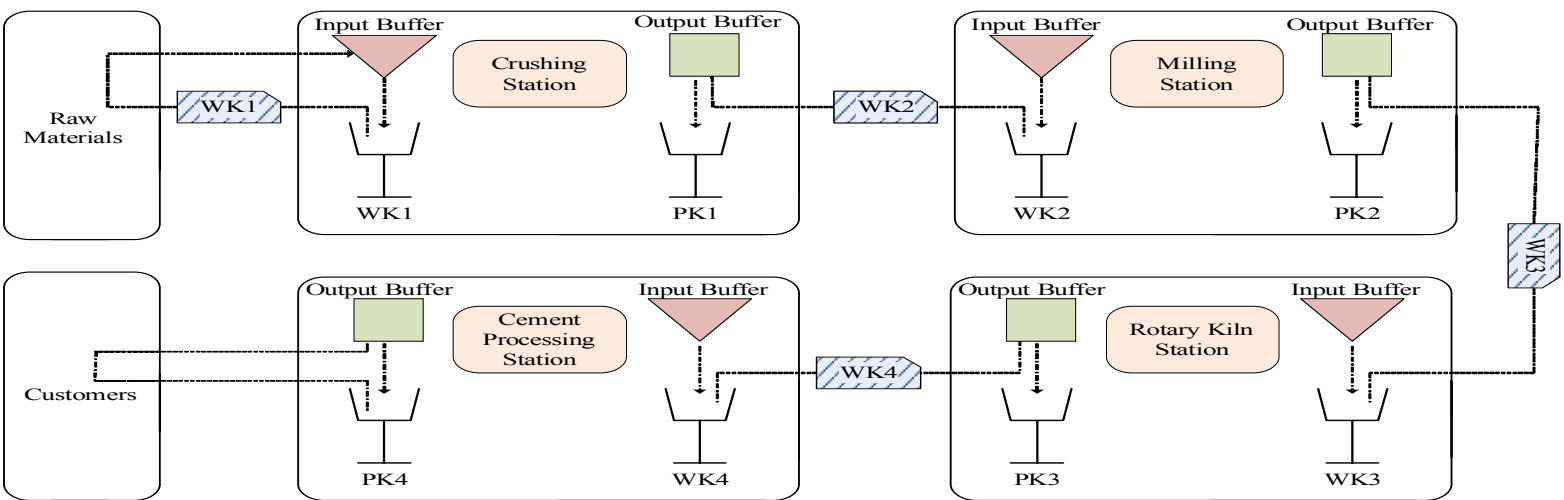

Fig. 5. Proposed Kanban in the cement production line.

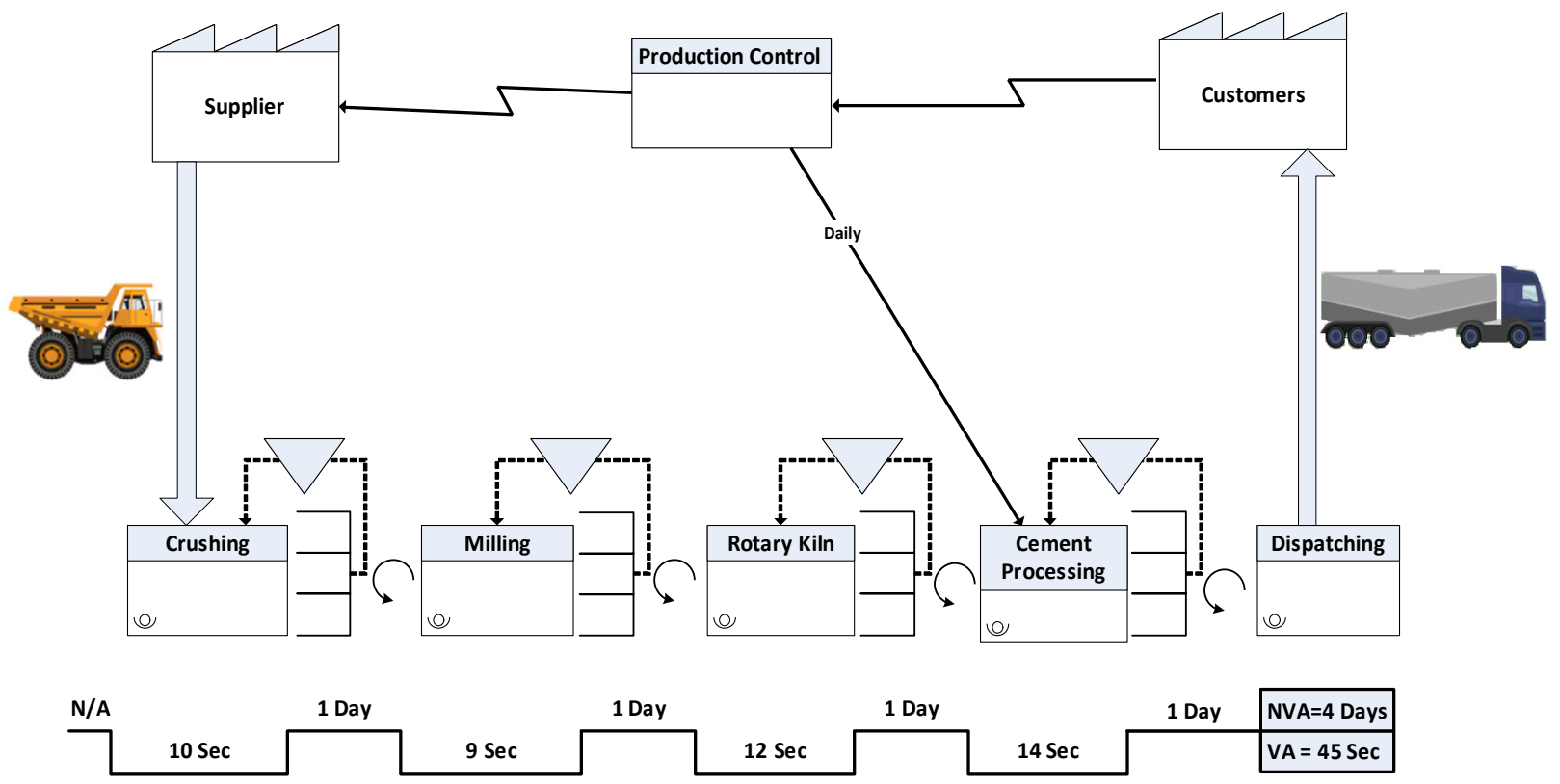

Fig. 6. Proposed VSM future state (Kanban).

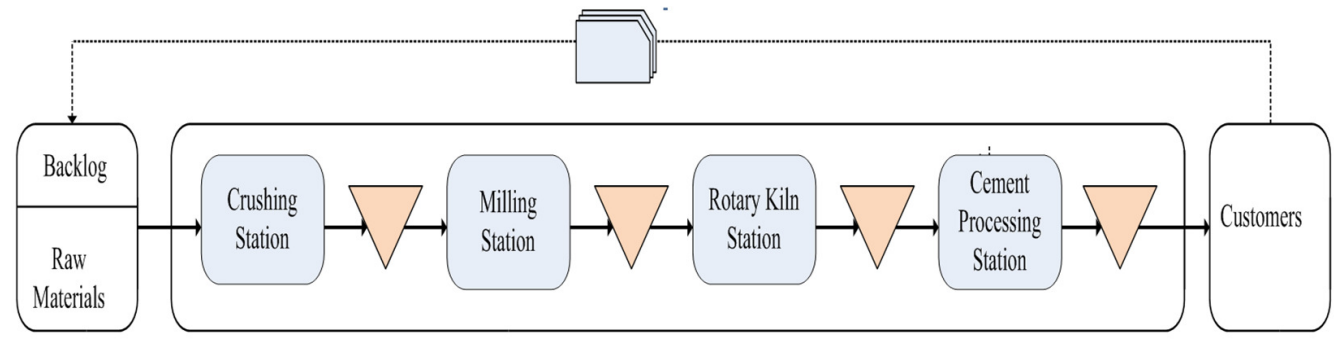

Fig. 7. The proposed CONWIP in the cement production line.

\section{B. CONWIP}

Figure 7 shows the proposed mechanism of CONWIP in cement production line. The assumptions are made by identifying the maximum WIP level in the cement production line, to ensure the level of inventory remains constant to the entire shop floor. The material flow directly enters the backlog. The backlog-sequencing rule in this proposed model is First In, First Out (FIFO). The required quantity of finished cement is dispatched to the customer. Then, the next customer orders can be initiated. The benefit gains of reducing the work cycle time according to the Little's law are [27]:

$$
\mathrm{WIP}=\mathrm{CT} \times \mathrm{TH}
$$

where $\mathrm{TH}$ is the throughput time that is the average output of a production process per unit time.

The future state map for the CONWIP approach is illustrated in Figure 8. 


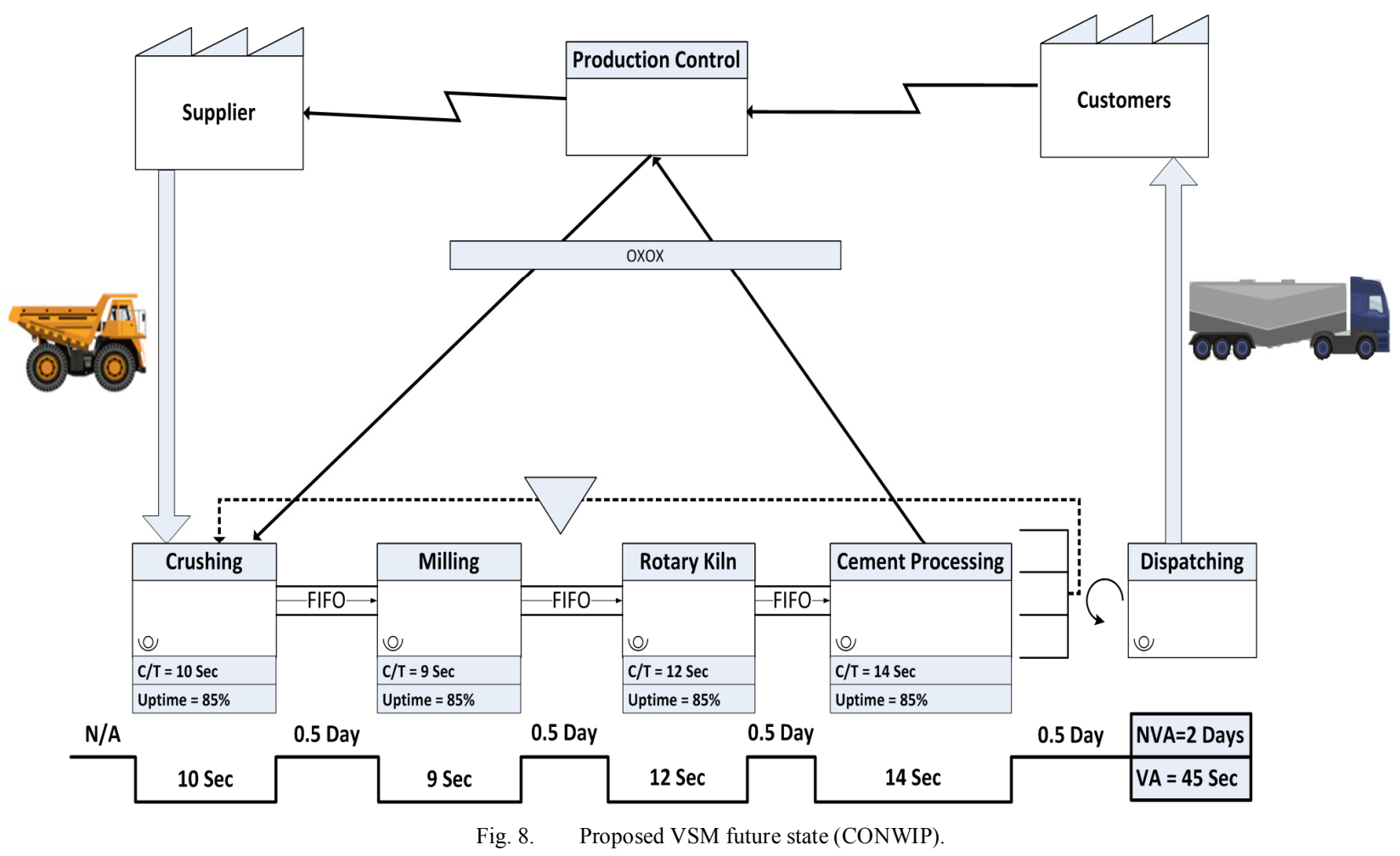

\section{RESULTS AND DISCUSSION}

The comparison between the current value stream map and the proposed future maps is presented in Figure 9.

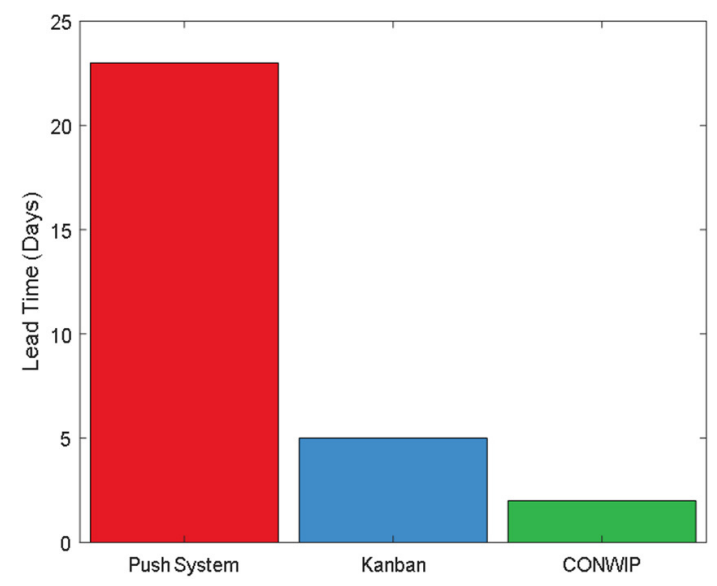

Fig. 9. Comparison of the push system and the pull systems.

It can be seen that the longest value of lead-time is about 23 days in the push production system, while in the proposed maps they are about 4 and 2 days for Kanban and CONWIP approaches respectively. The comparative results of non-value times in the cement production line for the proposed future maps is decreased by $50 \%$ in the scenario of CONWIP approach. The reason behind that is that there is no stock left between workstations in CONWIP. To illustrate, the finished cements are pulled out from the cement processing station which makes the production flows smoothly in the production line. In the case of push production system, the lead time is fixed as the material requirements are scheduled. The relationship between the level of work in progress, flow time and throughput rate is given in [27]. Due to the increase in the WIP level, flow time increases. Consequently, the increase in throughput hindrates and delays the production process and as a result, the production may get congested. Therefore, the recommendation is to implement the CONWIP approach to control the level of inventory in the cement production line.

A significant contribution of this paper is the study of the impact of the pull-based production system on the cement production line. It was shown that Kanban and CONWIP are tools capable of improving the shop floor process. They are able to control the excess inventories of clinker and cement and to eliminate the non-value activities in the cementmanufacturing environment. The outcome of this research is consistent with the foregoing findings. Authors in [21-25] reported that CONWIP is an appropriate approach to control the level of inventory. In addition, the findings could extend the methodology of [14] to implement lean production in cement industry. The future prospect is to extend this research further in order to implement a plan to construct the proposed VSM towards a cement production line.

\section{CONCLUSION}

The major issue in cement production process is the large inventories of clinker and cement. To cater and eliminate this issue, manufacturing strategies are applied. The VSM is a significant tool to evaluate the current state of manufacturing processes. The pull production systems (Kanban and CONWIP) produce the right quantities in the right time by 
controlling the inventory level. Both the proposed models are capable of improving the environment of cement manufacturing processes.

There are further possibilities for future research. The design of experiments to run simulation models should be considered. In addition, the possibility of applying the lean manufacturing model in cement Industry 4.0 should be explored. It is important to understand the dynamic manufacturing environment of the cement industry. The scheduling for dispatching products to customers based on the demand or the identification of time waste and bottlenecks during the cement production processes could be arranged by the integrated lean production with value stream tools to represent the real time and dynamic value chain of information and materials flows.

\section{ACKNOWLEDGMENT}

The author wishes to acknowledge the support of this research study by the grant No. ENG-2017-1-7-F-7137 from the Deanship of Scientific Research of Northern Border University, Arar, Kingdom of Saudi Arabia.

\section{REFERENCES}

[1] G. A. Rankin, "Portland cement," Journal of the Franklin Institute, vol. 181, no. 6, pp. 747-784, Jun. 1916, https://doi.org/10.1016/S00160032(16)90148-0.

[2] J. F. Ryan, "The story of Portland cement," Journal of Chemical Education, vol. 6, no. 11, pp. 1854-1868, Nov. 1929, https://doi.org/ 10.1021/ed006p1854.

[3] P. E. Halstead, "The Early History of Portland Cement," Transactions of the Newcomen Society, vol. 34, no. 1, pp. 37-54, Jan. 1961, https://doi.org/10.1179/tns.1961.003.

[4] V. A. Kaiser, "Computer control in the cement industry," Proceedings of the IEEE, vol. 58, no. 1, pp. 70-77, Jan. 1970, https://doi.org/10.1109/ PROC.1970.7541.

[5] D. Le Sar, "The production of sulphate-resisting and marine cements from local raw materials," Ph.D. dissertation, Department of Chemistry, The University of Cape Town, Cape Town, South Africa, 1964.

[6] A. Sicakova, E. Kardosova, and M. Spak, "Perlite Application and Performance Comparison to Conventional Additives in Blended Cement," Engineering, Technology \& Applied Science Research, vol. 10, no. 3, pp. 5613-5618, Jun. 2020, https://doi.org/10.48084/etasr.3487.

[7] M. E. Porter, Competitive Advantage: Creating and Sustaining Superior Performance. New York, NY, USA: Free Press, 1998.

[8] M. T. Fernandes, "Value Analysis: Going into a Further Dimension", Engineering, Technology \& Applied Science Research, Vol. 5, No. 2, pp. 781-789, 2015, https://doi.org/10.48084/etasr.535.

[9] T. Ohno and N. Bodek, Toyota Production System: Beyond Large-Scale Production, 1st ed. Cambridge, MA, USA: Productivity Press, 1988.

[10] J. P. Womack, D. Jones, D. Roos, The Machine That Changed the World. New York, NY, USA: Rawson Associates, 1990.

[11] M. Rother, J. Shook, J. Womack, and D. Jones, Learning to See: Value Stream Mapping to Add Value and Eliminate MUDA, 1st ed. Cambridge, MA, USA: Lean Enterprise Institute, 1999.

[12] J. K. Liker, The Toyota Way: 14 Management Principles from the World's Greatest Manufacturer, New York, NY, USA: McGraw-Hill, 2004.

[13] T. Tourki, "Implementation of Lean Within the Cement Industry," Ph.D. dissertation, De Montfort University, Leicester, UK, 2010.

[14] S. Deo, "Methodology to implement lean manufacturing in cement industry," M.S. thesis, Lamar University, Beaumont, TX, USA, 2013.

[15] M. Graisa and A. Al-Habaibeh, "An investigation into current production challenges facing the Libyan cement industry and the need for innovative total productive maintenance (TPM) strategy," Journal of Manufacturing Technology Management, vol. 22, no. 4, pp. 541-558, Jan. 2011, https://doi.org/10.1108/17410381111126445.

[16] A. M. Saifuddoha, M. A. Habib, S. Y. Sumi, S. Jennurine, and M. S. Islam, "Minimization of waste by applying value stream mapping in the supply chain of cement industry," IOSR Journal of Business and Management, vol. 9, no. 3, pp. 79-84, 2013, https://doi.org/10.9790/ 487X-0937984.

[17] M. I. Qureshi, M. Iftikhar, M. N. Bhatti, T. Shams, and K. Zaman, "Critical elements in implementations of just-in-time management: empirical study of cement industry in Pakistan," SpringerPlus, vol. 2, no. 1, Dec. 2013, Art. no. 645, https://doi.org/10.1186/2193-1801-2-645.

[18] E. Alghadafi and M. Latif, "Simulation of a Libyan Cement Factory," in Proceedings of the World Congress on Engineering $2010 \mathrm{Vol}$ III, London, UK, Jul. 2010.

[19] B. Noche and T. Elhasia, "Approach to Innovative Supply Chain Strategies in Cement Industry; Analysis and Model Simulation," Procedia - Social and Behavioral Sciences, vol. 75, pp. 359-369, Apr. 2013, https://doi.org/10.1016/j.sbspro.2013.04.041.

[20] E. Amrina and A. A. A. Lubis, "Minimizing Waste Using Lean Manufacturing: A Case in Cement Production," in 4th International Conference on Industrial Engineering and Applications (ICIEA), Nagoya, Japan, Apr. 2017, https://doi.org/10.1109/IEA.2017.7939181.

[21] R. P. Marek, D. A. Elkins, and D. R. Smith, "Understanding the fundamentals of Kanban and CONWIP pull systems using simulation," in Proceeding of the 2001 Winter Simulation Conference, Arlington, VA, USA, Dec. 2001, vol. 2, pp. 921-929, https://doi.org/ 10.1109/WSC.2001.977394.

[22] M. L. Spearman, D. L. Woodruff, and W. J. Hopp, "CONWIP: A pull alternative to kanban," International Journal of Production Research., vol. 28, no. 5, pp. 879-894, 1990, https://doi.org/10.1080/ 00207549008942761.

[23] M. Bertolini, M. Braglia, G. Romagnoli, and F. Zammori, "Extending value stream mapping: The synchro-MRP case," International Journal of Production Research., vol. 51, no. 18, pp. 5499-5519, 2013, https://doi.org/10.1080/00207543.2013.784415.

[24] M. L. Spearman and M. A. Zazanis, "Push and pull production systems. Issues and comparisons," Operations Research., vol. 40, no. 3, pp. 521532, 1992, https://doi.org/10.1287/opre.40.3.521.

[25] W. J. Hopp and M. L. Spearman, Factory Physics, 3rd ed. New York, NY, USA: McGraw-Hill, 2008.

[26] L. J. Krajewski and L.P. Ritzman, Operations Management: Strategy and Analysis, 6th ed. New Jersey, NJ, USA: Prentice Hall, 2001.

[27] J. D. C. Little, "A Proof for the Queuing Formula: L $=\lambda \mathrm{W}$," Operations Research, vol. 9, no. 3, pp. 383-387, Jun. 1961, https://doi.org/ 10.1287/opre.9.3.383. 